Available online at www.jmle.org

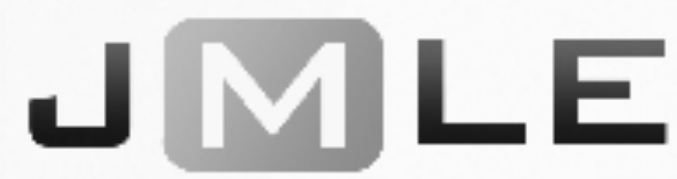

The National Association for Media Literacy Education's

Journal of Media Literacy Education 10 (1), 59 - 81

\title{
Media Literacy Policy in Flanders Belgium: From Parliamentary Discussions to Public Policy
}

\author{
Leo Van Audenhove \\ Mediawijs.be \& iMEC-SMIT-Vrije Universiteit Brussel \\ University of the Western Cape
}

Ilse Mariën
iMEC-SMIT-Vrije Universiteit Brussel

Hadewijch Vanwynsberghe

Mediawijs.be

\begin{abstract}
Media literacy has gained in importance in policy discussions on media, digital media and the Internet in many countries. How do these policies develop and what can be learned? This case study explores the factors contributing to the successful formulation and implementation of media literacy in Flanders-Belgium. By examining the trajectory of policy debates and policy formulation, this research highlights the development of the concept of mediawijsheid (media literacy), the organization, the Knowledge Center for Media Literacy, and the role of the public service broadcaster in relation to media literacy policy. This case study shows that media literacy has been supported through three coalition governments in Flanders Belgium as different political parties rallied around media literacy as a common denominator for the challenges posed by the changing digital media environment. In particular, the empowerment view on media literacy seems to charm the left, middle, and right of the political spectrum, a finding that may inspire other actors in other countries as they attempt to move media literacy onto the national political agenda.
\end{abstract}

Keywords: media literacy, media education, policy, Flanders, Belgium

Over the last decade, media literacy has gained in importance in policy discussions on media, digital media and the Internet in many countries. In Europe, Media literacy has been integrated into national and regional policies on media and education at the level of member states and the level of the European 
Commission. New organizations have been set up to promote aspects of media literacy such as Mediawijzer.net in the Netherlands or the Knowledge Center for Media Literacy (mediawijs.be) in Flanders/Belgium. Existing institutions have seen their mandate renewed or broadened to include aspects of (digital) media literacy such as OFCOM in the UK, the Bayerische Landeszentrale für Neue Medien (Bavarian Regulatory Authority for New Media) in Bavaria - Germany or the Agencija za elektronicke medije (Agency for Electronic Media) in Croatia.

As occurs so often (apart from the case of the United Kingdom), very little is known on how the different EU member states-or regional states for the federal countries such as Germany and Belgium-approach media literacy, how this is translated into national policy, and how policy is put into practice. Although the Journal for Media Literacy Education and other scientific journals from time to time publish articles on single countries, they often focus on particular initiatives and seldom focus on national policy.

In 2014 the TRANSLIT project gathered 28 country case studies on Media and Information Literacy Policies accessible via its website www.translit.fr. These case studies resulted in a comparative study published in an edited volume on Public Policies in Media and Information Literacy in Europe (Frau-Meigs, Velez, \& Michel, 2017). In 2016 the European Audiovisual Observatory published a report Mapping of Media Literacy Practices and Actions in EU-28. This report was commissioned by the Council of Europe and provides an overview of media literacy practices in the different countries (Nikoltchev, Cappello, Cabrera, Valais, \& Chapman, 2016). As valuable as they are, in general, a drawback of these comparative initiatives is that they are based on commissioned case-study research using pre-formatted documents with strict editorial guidelines. These case studies focus on comparability instead of on the specificity and particularities of the national case. ${ }^{1}$

This article provides an in-depth view of one single nation/region. Single country case-study research on policy and policy implementation can be a source of inspiration for more localized solutions to media literacy policy and implementation. The aim of this article is to focus on the political discourses and policy developments around media literacy in Flanders - Belgium. In Flanders, the discussion on media literacy started in the Flemish Parliament in 2006 but only in 2012 was a comprehensive policy document on media literacy and education adopted by the government. This Media Literacy Concept Paper was jointly developed and signed by the Minister of Media and the Minister of Education and Youth, which resulted in a broad definition of media literacy and a transversal approach to implementation.

In this case study, we (1) discuss three major trends in the current debates on media literacy that have implications for policy; (2) analyze the parliamentary discussions on media literacy in Flanders; (3) introduce and analyze the Media Literacy Concept Paper; (4) discuss the establishment of the Knowledge Center

\footnotetext{
${ }^{1}$ Furthermore, in both studies, only scant attention is paid to policy and policy discourse. The main author of this article was also the author of the case-studies on Flanders and Belgium commissioned for both the book and report mentioned above.
} 
for Media Literacy (mediawijs.be); and (5) discuss the role of the public broadcaster. We conclude by formulating observations in light of the future.

\section{Media Literacy Policy and Current Theoretical Debates}

It is not our aim to provide readers with an in-depth overview of the current conceptual and theoretical discussions about media literacy. Instead, we aim to identify a couple of trends in these discussions that have a strong link to the public debate and policy around media literacy. Whereas media education and media literacy have been at the fringes of public policy for many years, in recent years media literacy has become a central point of debate in media and educational policies in many countries and especially in European countries. Some of the theoretical discussions in the media literacy field have direct links with the broader policy discussions. We identify three main trends in the discussion.

First, over the last decades, we have witnessed a trend away from protectionist media literacy approaches towards empowerment literacy approaches. The protectionist approach starts from the idea that media has negative effects on people (especially youngsters) and that users are more susceptible if they are passive (Potter, 2013). The protectionist approach is informed by two distinct theoretical schools in communication studies, i.e., media effects studies, and critical political economy. The first, media effects studies, focus on short and long-term effects of media and content such as advertising, violent content, etc. on peoples thinking and behavior. The latter, critical political economy, sees the media as an ideological tool of capitalism that supports the capitalist system and inherently misrepresents reality. The empowerment, emancipatory or promoting approach starts from the idea that media forms an integral part of our mediated society. Users (including youngsters) are seen as capable of actively engaging with media. Media literacy should stimulate them to become more autonomous in their critical engagement with media and ICTs (Jenkins, 2006; Brian O’Neill \& Barnes, 2008; von Feilitzen \& Carlsson, 2003). The emancipatory approach often promotes the idea that education about media should start from content, programs, and applications that users watch or use. The emancipatory approach is theoretically close to cultural studies and constructivist approaches in education.

Second, the heightened attention to media literacy is closely related to shifts in media, telecommunication and Internet regulation. Growing digitalization is transforming all users into active producers of content (Hoechsmann \& Poyntz, 2012), while the blurring of boundaries between linear broadcasting and digital content provision has diminished the impact of protective measures. As a consequence, a model of 'co-responsibility' has recently gained traction at the European level (Marsden, 2011). As audiences can consume more content in pull mode, individual responsibility and self-regulation are becoming significantly more important than protective measures (Wallis \& Buckingham, 2013). Media literacy action is more and more seen as a way to enhance critical skills and user autonomy in the absence of strict media regulation (B. O'Neill, 2010; Wallis \& Buckingham, 2013). 
Third, most authors on media literacy advance a skills-based approach to media literacy (Livingstone, 2004; Potter, 2014), which guides the vast majority of research initiatives on the subject. Potter identifies seven cognitive skills: analysis, evaluation, grouping, induction, deduction, synthesis and abstraction (Potter, 2013). The skills-based approach is related to other skills and competences discussions currently taking place, especially around digital skills, eskills, Internet skills, coding skills, etc. Whereas media literacy initially focused on cognitive skills to deconstruct media and media content, digital skills discussions focus much more on operational skills to be able to use technology. Currently, both debates often run parallel.

However, recent theories in media literacy start to focus on the creative and communicative skills needed to handle interactive aspects of media and Internet. Digital skills frameworks integrate more cognitive or strategic skills in their frameworks or competence models (Hobbs, 2011a; Hoechsmann \& Poyntz, 2012; Wallis \& Buckingham, 2013). In principle, they are all grappling with increasingly converged media. This being said the underlying-and often unformulated-goals of media literacy and e-skills frameworks are different. Media literacy is informed by broad humanistic and aesthetic goals about citizenship and enjoyment of media, entertainment, games, culture, and art. eSkills debates are informed by much more utilitarian goals such as employment, economic development, and direct individual enlightenment. In this sense, the eskills debate largely neglects the fact that media in general and social media in particular play an important social and entertaining function in people's day-today life.

\section{Parliamentary Discussions on Media Literacy in Flanders}

Media literacy in Flanders - Belgium should be seen against the educational, political and institutional developments in Belgium over the last 4050 years. Between 1970 and 2014, Belgium developed from a centrally organized country with three languages, towards a decentralized federal system in which the different communities - based on language and territory - have a high level of autonomy. ${ }^{2}$ The Belgium institutional setup is highly complex and changed gradually in the forms of 6 State Reform. Simply put, the current Belgian system consists of one national state with its government/parliament and three communities: the Flemish Community, the French Speaking Community and the German Community and three regions: Flanders, Wallonia and the Brussels Capital Region with their governments/parliaments. The communities - especially the larger Flemish and French Speaking Community - are responsible for person-

\footnotetext{
${ }^{2}$ Culturally and sociologically, it refers to Flemish organizations, media, social and cultural life; alternative expressions for this concept might be the "Flemish people" or the "Flemish nation" (in a similar sense as the Scottish, Welsh, or Québécois people are nations, referring to an ethnic identity). The term "community" should then not be capitalized. Politically, it is the name of which both elements are normally capitalized, for one of the three institutional communities of Belgium, established by the Belgian constitution and having legal responsibilities only within the precise geographical boundaries of the Dutch-language area and of the bilingual area of Brussels-Capital (Wikipedia).
} 
related matters amongst which education, culture, and media. Media literacy is thus a community matter under the remit of the Flemish Parliament and the Flemish Government.

As in most countries, the current media literacy debates have precursors in earlier initiatives. The current debate on media literacy in Flanders has different antecedents: (1) the discussion on media and cultural education which predates the current discussion, but seldom reached the political level, (2) developments in the field of the digital divide and e-inclusion which are the result of the gradual digitalization of media and society. In this article, we will focus on the new discussion, which emerged in the Flemish Parliament in 2006 with discussion on mediawijsheid, a term that can be literally translated as media wisdom but is largely synonymous with the term media literacy in English.

The term has evolved over time. In the databank of the Flemish Parliament, the search term mediawijsheid pops-up 647 times since 2006. This databank contains all transcripts of discussions in parliament, the discussions in the commissions and their hearings, all draft laws and final laws put to the vote before parliament since 1970 when it was established. Apart from mediawijsheid, other terms have been used, including mediageletterdheid (media literacy), which appears 104 times since 2004; media-educatie (media education) which appears 124 times since 1995; and media-opvoeding (another word for media education) which appears 73 times since 1997. ${ }^{3}$ Two broad observations can immediately be made. First, before 2006 parliament discusses media education from time to time, but with a low frequency. Today, mediawijsheid has emerged as the central concept in parliamentary discussions on media literacy and the term is mentioned manifold times in comparison to the period before 2006.

The term mediawijsheid first popped up in a meeting of the Commission for Culture, Youth, Sports and Media in June 2006. The Commission discussed the reform of the Film Screening Authority in the context of the protection of minors in the audiovisual and gaming sector. A member of the social-democrat party sp.a refers to the Dutch Kijkwijzersysteem - a film rating system introduced in the Netherlands - and suggests a more empowerment-oriented approach to the protection of minors concerning film and gaming. He noted:

We have to make sure that we have the necessary instruments to guide children who watch television and play games. We need to make sure that children themselves have the necessary instruments to engage with media in a savvy way. I refer to the Netherlands where they no longer use the term media education, but media wisdom (mediawijsheid). I think this is an interesting concept because, on the one hand, it indicates that parents and teachers have a certain responsibility, but on the other hand that children are indeed able to handle media sensibly" (Joris Vandenbroucke in Vlaams Parlement (2006), our translation).

The then Minister of Culture, Youth, Sports, and Brussels responded positively to the use of the term mediawijsheid, noting:

\footnotetext{
${ }^{3}$ Search carried out in August 2017.
} 
We can ask the question whether it is necessary that the government intervenes in sectors where certain branches of the media sector have developed a system of self-regulation. (...) I am not in favor of introducing a system that prohibits the sales of certain (violent) games. (...) An information system which leads to discussions between parents and educators and children is in my view much more appropriate. In that sense it might indeed be better to talk about media wisdom (mediawijsheid)" (Bert Anciaux in Vlaams Parlement (2006), our translation).

Two years later, in May 2008, in a meeting of the Parliamentary Commission on Media-again in the context of a discussion on gaming-a member of the Christian democratic party CD\&V asked the Minister of Culture, Youth, Sports and Brussels the following question:

In the Netherlands, they want to establish a center of expertise that supports parents and schools in how to function in a virtual world. My question, therefore, is whether you foresee the funding of projects in media literacy. (...) Would you be in favor of establishing such a center (in Flanders) and do you see this as a role for you as Minister in charge of children's rights and youth?" (Tinne Rombouts, Vlaams Parlement (2008b), our translation).

The same member of parliament tabled this question on several occasions to different ministers, amongst others to the Minister of Foreign Affairs, Media and Tourism, Geert Bourgeois (Vlaams Parlement, 2008a) and the Minister of Work and Education, Frank Vandenbroucke (Vlaams Parlement, 2008c). Both were reluctant to support the idea. The Minister of Media referred the matter to the public broadcaster who indirectly contributes to knowledge on media. The Minister of Education indicated that schools are already supposed to work on media and that media education is part the final attainment level.

Parliament is however not dissuaded. On May $5^{\text {th }} 6$ Members of Parliament introduced a resolution in support of the gaming sector in Flanders. The resolution covered different topics such as gaming, a rating system for the gaming sector, support to the gaming sector in Flanders, and media literacy. In the resolution, gaming is not perceived negatively but is seen as a potentially positive medium and as a cultural product in its own right. The resolution formulated recommendations about the self-regulation of the gaming sector, in line with PEGI, about control over self-regulation, focusing on the potential educational value of games and proposing measures to stimulate the gaming sector as a service and creative sector in Flanders. This resolution is supported by Christian Democrats CD\&V, Social Democrats sp.a, conservative nationalists N-VA, Liberals Open VLD and the Green Party Groen. The resolution is thus supported by all major coalition and opposition parties, except for the ultra-nationalist party Vlaams Belang. 
Concerning media literacy, the document states:

The members of parliament submitting this resolution are convinced that a Knowledge Center for Media Literacy, in line with developments in the Netherlands and the UK, can contribute considerably to parent's and children's critical and appropriate use of games, the Internet, and other media. (...) The Flemish Parliament (...) asks the Flemish Government: (...) $4^{\circ}$ to establish a Knowledge Center for Media Literacy within the Flemish Regulator for the Media, that would gather knowledge in relation to technological developments, that would carry out or outsource research on the educational effects and possibilities of new media such as the Internet, games, and interactive software, and that would establish campaigns to inform youth, parents, teachers and educators, in collaboration (with other organizations). (our translation, Vlaams Parlement, 2008d).

The Resolution was adopted by Parliament on July 9, 2008 and had a direct effect on policy. In a Policy Brief of October 2008 by the new Minister of Media-and Minister-President of Flanders at the same time - the concept of mediawijsheid is first mentioned in a government text. Media literacy appears in the context of news in a digital age and opinion formation by citizens through digital media. The document is fairly negative about news in a digital age. It concludes that:

The most relevant new factor (regarding a solution) is probably the teaching of media literacy. (...) Readers, listeners, and viewers must be educated to be able to evaluate and assess the value of the content presented to them. That is what media literacy means: to be able to handle the multitude of constructed information responsibly, to be able to sort the wheat from the chaff and to develop a critical attitude towards the sometimes biased news" (our translation, Peeters, 2008).

The document remains vague on how to implement the policy. It does consider the establishment of a Knowledge Center but indicates that the Flemish Regulator for the Media is carrying out a comparative analysis to look at the different organizational options. These options were presented to the Commission for Media of the Flemish Parliament in March 2009 (Vlaams Parlement, 2009) and led to discussions on how and where best to establish a Knowledge Center. These discussions were technical and political in the sense that some political parties feared that specific options might influence the independence of such a center. A decision would only be taken by the next government after the general elections. However, what is clear from the analysis above reveals is that:

1. In Flanders, media literacy emerged on the parliamentary agenda after 2006;

2. It is not the government, but parliament and more specifically the Commission on Media that is driving the agenda; 
3. There is broad support for the topic from all democratic parties both from parties within the governing coalition as from opposition parties;

4. The initial discussions are sparked by the possible negative effects of digital media, in relation to gaming and in relation to news and opinion formation;

5. The discussion on media literacy is linked to the discussion on regulation of the media by government in the form of self-regulation or co-regulation between government and industry;

6. The individual-including children-are thought to be able to handle media in an independent, sensible and critical way.

Figure 1 provides a chronological overview of the formal policy in relation to media literacy, which will be discussed in the following sections. Within Parliament, media literacy remains a topic that is regularly discussed, especially in the Commission on Media and the Commission on Education. Figure 1 shows the historical development of policy as formulated by the Minister of Media. Other policy texts-especially in Education-do have provisions about media literacy or briefly refer to it-however, it is the Minister of Media who takes the lead in formulating a policy on media literacy. Regarding the implementation of policy, the educational sector is, of course, an important sector to reach kids and adolescents. Both the education department and the Knowledge Center for Media Literacy will thus, in their implementation strategies, pay specific attention to schools. However, this article focuses on formal policy and less on implementation.

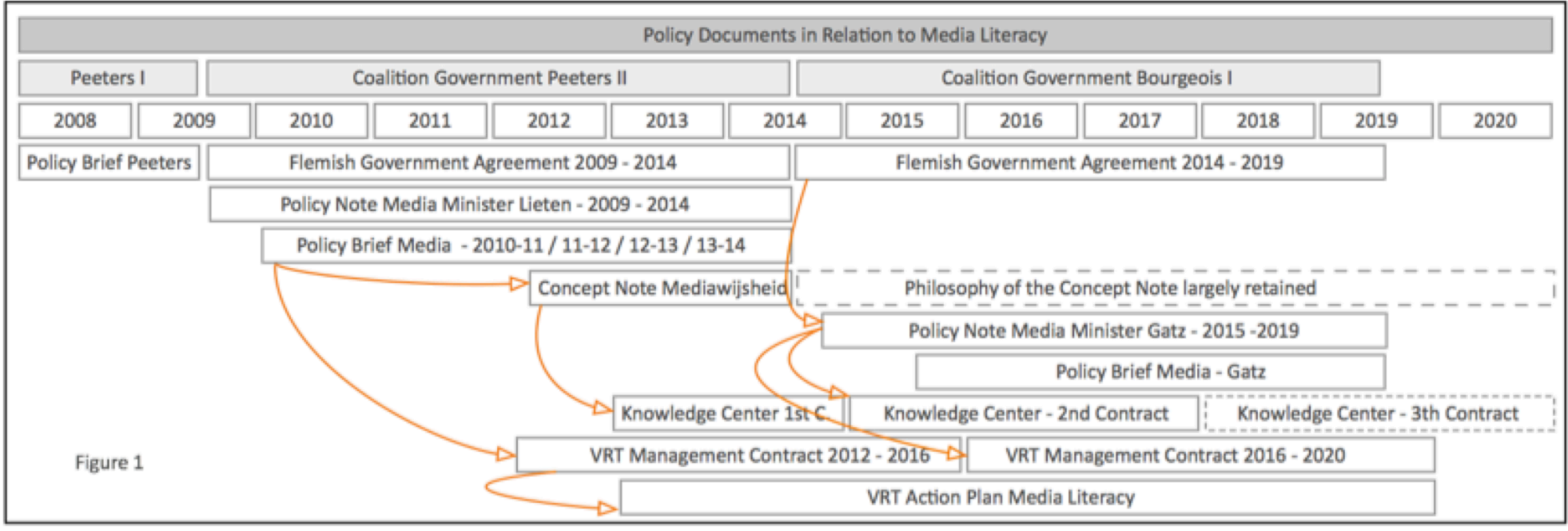

Figure 1

Media Literacy under the Coalition Government Peeters II 2009-14 


\section{Government Agreement and Ministers Policy Note}

From 2009 to 2014, the coalition government Peeters II consisted of Christian Democrats CD\&V, Social Democrats sp.a, and Conservative Nationalists N-VA. They were the first government that officially mentioned media literacy in its Government Agreement. This agreement set out the broad policy lines the government wished to achieve within its five-year mandate. In the Government Agreement 2009-2014, three provisions are related to media literacy: (1) overcoming the digital divide; (2) providing universal access to the Internet at democratic prices; and (3) making citizens more media literate (Vlaamse Regering, 2009). In the Government Agreement, the establishment of a Knowledge Center for Media Literacy is promised:

Media users have to acquire the necessary skills to be able to use new media adequately. We, therefore, establish a Knowledge Center for Media Literacy that will coordinate the collaboration on media literacy with all partners in the sector. Information campaigns need to developed using channels many people are using - via the Internet and more specifically using social media (our translation, Vlaamse Regering, 2009).

The policy concerning media literacy is further developed in the Ministers Policy Note 2009-2014 by the appointment of the Minister for Media, Ingrid Lieten. ${ }^{4}$ In this Policy Note, which is meant to specify the policy for the whole government period 2009-14, media literacy is broadly defined. The brief proposed an open and modern vision on media literacy with a focus on both creation and critical thinking about all forms of media:

Media literacy has many layers: being able to handle all existing media, being able to actively use media, critically engaging with media, creatively using media in terms of producing/making media 'user-generated content', understanding the economics of the media, being aware of the authors and copy right issues related to digital media in our society"(our translation)(Ingrid Lieten, 2009).

Interesting to note is that there is an emphasis in the document on the needs of specific vulnerable groups:

The Knowledge Center for Media Literacy will in all of this pay special attention to the needs of specific groups under which children, youth and senior citizens, but also specifically to vulnerable groups in society such as people with disabilities of those who live in poverty (our translation, Ingrid Lieten, 2009).

\footnotetext{
${ }^{4}$ In Flanders, a distinction should be made between a Ministers Policy Note and a Policy Brief. In the Policy Note, the Minister sets out its broad ambitions for the five-year term of his/her mandate in a specific field. The Policy Brief specifies concrete actions in the same field for two years.

Flemish Ministers are responsible for multiple fields and will, therefore, develop different of these Notes and Briefs during their mandate.
} 
In her Policy Brief for the period, 2010-11 Minister of Media Ingrid Lieten further developed her policy on media literacy to include a funding mechanism. In the Policy Brief, 650,000 euros was made available to support media literacy projects in Flanders. In this policy document, media literacy was linked to e-inclusion, the digital divide of the second degree, stereotyping and representation, skills and diversity, as this excerpt shows:

Quality is closely linked to access and innovation. The complexity of media has as an effect that sometimes 'media victims' occur-e.g., young people who are stalked or bullied on the Internet. A new divide is emerging between those who are media literate and those who are not. Additionally, we notice that disadvantaged groups (...) feel excluded because of continuous stereotyping representations. It is my firm belief that each Flemish citizen should be able to handle (new) media appropriately and should recognize herself in specific segments of media content. Especially as our society has become more diverse, it is of utmost importance that diversity is recognized and appreciated (our translation, Ingrid Lieten, 2011).

\section{Concept Brief on Media Literacy}

In 2012, a coherent media literacy policy was jointly developed by the Ministry of Media Ingrid Lieten and the Ministry of Education Pascal Smet. Both Ministers belong to the social democratic party sp.a. The Concept Brief Media Literacy (Conceptnota Mediawijsheid) had the broad ambition to develop a framework for media literacy that reaches beyond the fields of media and education. The document states:

Media literacy is a theme that touches diverse aspects of policy such as media, innovation, youth, education, culture, welfare and poverty reduction. This concept brief mainly focusses on the fields of media and education, yet it is an invitation to broaden the collaboration and the policy approaches" (our translation, Lieten \& Smet, 2012).

In the Concept Brief, media literacy is defined as:

(...) the whole of knowledge, skills, and attitudes that allow citizens to deal with the complex, changing and mediatized world in a conscious and critical way. It is the ability to use media in an active and creative way, aimed at societal participation" (our translation, Lieten \& Smet, 2012).

This definition reflects very well the philosophy and tone of the whole Concept Brief. It takes a somewhat neutral position as to the role of media in society and starts from the observation that our view of the world is a mediated one and that citizens need to be aware of this. The Concept Brief also stresses that users are becoming more active participants due to the digitalization of media. The 
definition, therefore, stresses that users need the ability to actively and creatively use media. The goal of media literacy is societal participation. Whereas in other countries media literacy is often the result of a negative view on the effects of media (for an analysis of policy in the UK, see (Wallis \& Buckingham, 2013)), the Concept Brief mainly takes an empowerment view. The document explicitly specifies this:

We start from a positive pedagogy/approach that does not start from fear nor from banning media or prohibiting media use, but from an emancipatory vision in which media is used for self-expression (our translation, Lieten \& Smet, 2012).

A primary focus is thus put on the active use of media starting from the view that '(...) competences are already present in young persons' (our translation)(Lieten $\&$ Smet, 2012). The Concept Brief is not blind for some of the negative aspects of media nor the 'dangers' of social and interactive media such as cyberbullying, sexting and grooming, but policy should 'strive for a balance between 'emancipation' and 'protection' (Lieten \& Smet, 2012). For the developers of the Concept Brief, it is thus apparent that media literacy necessitates a heightened level of self-regulation by the individual citizen. The policy states:

Instead of searching for answers in a multitude of regulatory measures the goal is to make citizens more resilient, alert and critical. From a user, perspective suggestions are offered that help to use different media in a positive and independent way (our translation, Lieten \& Smet, 2012).

The Concept Brief on Media Literacy identified four strategic goals that are central to the current policy in Flanders. The strategic goals are in the Concept Brief discussed at length. We summarize them here briefly:

1. Creating a strategic framework in Flanders. The Concept Brief was seen as the start of a broader set of activities involving other stakeholders and policy fields. The document described the different institutions and actors and their possible role in media literacy.

2. Stimulating competences. A central focus of policy was in the development of knowledge, skills, and attitudes through both formal and informal learning. Being able to participate in society independently was seen as essential; both formal and non-formal education have a role to play.

3. Creating an e-inclusive society. Citizens should have equal opportunities in the information society. Particular attention suggested that media literacy addressed the needs of disadvantaged sections of society.

4. Creating a safe and responsible media environment. Especially for young people, reference was made to social media and issues related to privacy, cyberbullying and the role of parents, educators and youth workers in 
guiding children and young people in their media use (our translation, Lieten \& Smet, 2012).

Clearly, education is seen to play a central role in the realization of all of these goals. Media literacy is explicitly seen as a transversal issue that touches upon many different policy fields, terrains and includes different actors. The document referred at the Flemish level to the policy fields of media, education, youth, culture, welfare, innovation, and poverty reduction. It links to national policies for social integration, poverty reduction, social economy and urban development. At the level of cities and communes, the policy refers to the role of public access to media and new media. The Concept Brief mentioned the role of the regulator, the public broadcaster, commercial television and the radio sector, the written press, telecom operators, the gaming sector and the social network sector. It recognized the roles of formal education, higher education and universities, adult education, arts education and teacher training (Lieten \& Smet, 2012). In order to promote coordination, the Concept Brief reaffirmed government's intention to establish a dedicated Knowledge Center for Media Literacy and described its goals and functioning:

This Knowledge Center will in the first place build on existing-but scattered-initiatives and expertise and will coordinate them. It will take action if existing initiatives are insufficient or show lacunae. The Center will play a stimulating function with specific attention to the needs of specific target groups. The acquired knowledge should flow to all relevant actors in the media, cultural and educational fields (our translation, Lieten \& Smet, 2012).

\section{The Role of the Flemish Public Broadcaster}

Flanders is characterized by a dual media system with strong public service media, the Flemish Radio and Television (VRT). Public service media is a regional policy in Belgium. The Flemish public broadcaster VRT is very popular attaining market shares of about $40 \%$ for television and $60 \%$ for radio. Its public funding has decreased over the last decade. It now has a budget (combining 2/3 of public revenue with $1 / 3$ of commercial revenue) of about 400 million euros annually, which is at the bottom of Western and Northern European countries). The public broadcaster has a wide remit in the areas of information, culture, education, entertainment, and sports.

The government considers the three priorities: discussing difficult societal topics through documentary production, support for language skills, and also media literacy. The latter is specified as one of the tasks of VRT and related to people's participation in society and economy. Children, youngsters, and elderly people are identified as critical target groups of media literacy initiatives. Concerning the public broadcaster, the Concept Brief states that:

The VRT can, as part of its educational mandate, contribute considerably to media literacy. In its diverse programs and over the different channels it 
can help to stimulate the diverse competencies, and it can give space to listeners and viewers to create their own content. The VRT can develop an offer to make less competent media users aware of new applications and can open up her media archives to an as broad as possible audience (our translation, Lieten \& Smet, 2012).

This vision was - at about the same time the Concept Brief was releasedtranslated into the Management Contract 2012-16 between the Flemish Government and the VRT. This binding contract sets out the mission, goals, and indicators the public broadcaster has to achieve. Concerning media literacy, the Management Contract makes these stipulations in Strategic Goal 23:

23. The VRT contributes, as part of its educational remit, to the media literacy of all Flemish citizens.

23.1. The VRT contributes to a democratic and media-conscious attitude of its viewers by way of independent information about media and by way of inclusive general programming, learning citizens to engage more critically and consciously with media. The VRT shows citizens in its general programming the possibilities and risks of media applications (e.g., social media, gaming, ...) and aspects of media use (e.g., privacy).

23.2. The VRT actively works together with other stakeholders to support media literacy. Within a year after which this Management Contract takes force, this has to result in a dedicated action plan.

23.3. The VRT develops a specific and adapted program offer for kids, youngsters and digital immigrants to acquaint them with (new) media applications. The VRT offers specifically for this group the possibility of self-experimentation with creation and co-creation of media.

23.4. Within its budgetary means and its programming possibilities, the VRT supports the policy of the Flemish Government concerning media literacy (our translation, VRT, 2012).

The VRT translated the requirements of the Management Contract into its Action Plan on Media Literacy (VRT, 2013), which concretely indicated what television and radio programs will contribute to media literacy, particularly in relation to children, youth, and digital immigrants. Additionally, the VRT indicated that it will stimulate the consciousness about media literacy within its workforce:

(...) the VRT will make its collaborators aware of the importance of media literacy and inform them on how to integrate it in its offer (our translation, VRT, 2013).

An analysis of how the VRT has implemented this policy is outside of the scope of this article. What is clear is that as a direct result, the VRT has over the past five years supported many initiatives from third parties by providing airtime, 
integrating media literacy concepts into programming and promoting initiatives on its radio channels and television stations.

\section{Establishment of a Knowledge Center for Media Literacy}

In the summer of 2012, the Flemish government launched a call for proposals for the establishment of a Knowledge Center for Media Literacy (Departement Cultuur, Jeugd, Sport en Media, 2012). Its mandate is defined as follows:

The Knowledge Center for Media Literacy stimulates knowledge building and transfer from organizations and individual professionals within the broad field of media literacy. The Knowledge Center offers support for practical approaches and develops good practices. The Knowledge Center actively works together with relevant stakeholders from government and the media literacy movement and stimulates dialogue and collaboration between stakeholders' (our translation, Departement Cultuur, Jeugd, Sport en Media, 2012).

The document set out the strategic and operational goals for the Knowledge Center. Some elements included these provisions:

The Center adequately supports organizations working in the field in the development of knowledge and in the development of best practices:

- The Center keeps the mapping of the field of media literacy up-todate with a focus on needs, practices, organizations $(\ldots)^{5}$;

- The Center provides government and the field with information on current trends related to media literacy. It distributes research and publications appropriate for the sector;

- The Center operates close to the field and is aware of the issues at stake and the needs of the organizations in the field;

- The Center searches for and disseminates innovative practices and trends in support of organizations and practitioners in the field to inspire and contribute to new learning;

- The Center takes initiatives that bring together training, scientific research, and best practices;

- The Center takes initiatives to provide-and exchange- education and training concerning media literacy for the organizations and practitioners in the field;

- The Center contributes to structural exchange between organizations and creates collaborative networks within the field;

The Center is a partner for the Flemish Government regarding policy preparation and regarding policy implementation:

\footnotetext{
5 The government ordered a mapping exercise on media literacy in 2012 which was used as a background document to formulate its policy on media literacy (see: Vermeersch, Van den Cruyce, Vandenbroucke, \& Segers, 2012)
} 
- The Center provides Government with appropriate information on the stats of the media literacy field in Flanders;

- The Center provides Government with a platform to assess new policy initiatives and to develop new partnerships;

Media literacy thinking and practice are further spread (among the Flemish population):

- The Center actively disseminates up-to-date information on its work, available knowledge and relevant research to the broad public;

- The Center is a clearing house for the field and refers to the right organization in the field;

- The Center sensitizes actors in the field or the general public (our translation)(Departement Cultuur, Jeugd, Sport en Media, 2012).

From the description of the strategic and operational goals, it became clear that the Government wanted an intermediary organization in support of the already existing initiatives in Flanders. The region is characterized by a number of small and medium social and civil society organizations that play an important cultural role in society. A lot of these organizations focus on youth, media, culture, education, etc. and have activities that are linked or can be linked to media literacy (Bens, Segers, Boudry, Van Houcke, \& Mariën, 2014; Vermeersch, Van den Cruyce, Vandenbroucke, \& Segers, 2012). The government did not want to duplicate the work of these organizations. The document states that:

(...) (The Center) uses existing initiatives, mobilizes its knowledge and practices and raises awareness. (...) In short, the Knowledge Center does not 'duplicate' what already exists, it complements and strengthens (our translation, Departement Cultuur, Jeugd, Sport en Media, 2012).

Three consortia submitted proposals for consideration in 2012. After an evaluation procedure, the Government granted one of the consortia with the task to establish a Knowledge Center on Media Literacy. The consortium consisted of 12 partners from the media literacy field, Flemish Universities and Vocational Colleges ${ }^{6}$ This consortium selected five experts to form the core management of the Center. By selecting the experts from the ranks of the participating organizations, the Center became operational on January 1, 2013 (IBBT, 2012). The first contract ran for two years and the government translated the strategic and operational goals into measurable indicators (Vlaamse Regering, 2012).

\footnotetext{
${ }^{6}$ SMIT-Vrije Universiteit Brussel, MICT-UGent, Cemeso-Vrije Universiteit Brussel, ICRIKatholieke Universiteit Leuven, Javi-Jeugdwerknet vzw, Katholieke Hogeschool Limburg, LINC vzw, MAKS vzw, MIOS Universiteit Antwerpen, Provinciale Hogeschool Limburg, REC Radiocentrum, Thomas More Hogeschool, Stuurgroep Volwassenenonderwijs.
} 
Media Literacy under the Coalition Government Bourgeois I 2014-19 Moving closer to the present day, a new coalition government Bourgeois I formed in 2014, consisting of the conservative nationalist party N-VA, the Christian Democrat party CD\&V and Open VLD, the liberal party. This government's term started in the fall of 2015. The Flemish Government Agreement 2014-2019 only briefly mentioned media literacy and the role of the Knowledge Center for Media Literacy:

Media literacy and digital literacy are essential. We will close the digital divide. Also, vulnerable groups in society should have appropriate access to media and should be media literate. (...) Media users should acquire the necessary skills to be able to use (social) media. The Knowledge Center for Media Literacy should be able to develop a coordinated approach in collaboration with partners in the field and with policy domains such as education, welfare and culture' (our translation, Vlaamse Regering, 2014a).

However, in its Policy Note 2014-19, in which the new Minister of Culture, Media, Youth and Brussels, Sven Gatz, of the liberal party Open VLD, set out his views on media policy. In this document, Gatz reaffirmed the importance of media literacy. What is even more, he made media literacy the central theme of his ministry for the five-year term. The document puts the user squarely in the center of media policy:

The media policy I will deploy, in the first place starts from the user. The user must be able to use media consciously and critically, especially in the current digital broadband era in which the user does not passively receive media, but actively participates in the media. Active use requires accessible and affordable media. I will by way of an appropriate media literacy policy prepare all users for the digital society (our translation, Gatz, 2014).

The Policy Note 2014-19 provisions on media literacy were in line with the Concept Paper Media Literacy of the former government. However, the new minister did not put his accents. Apart from a stronger emphasis on the individual responsibility of the user, the document focused more on future trends and changes in current media landscapes:

With the further development of a proactive and future-oriented Flemish media literacy policy, I want to anticipate emerging trends and new forms of media. The aim is that the Flemish citizen learns to actively and critically engage with the media of today, to prepare for the new media of tomorrow" (our translation)(Gatz, 2014).

The Knowledge Center for Media Literacy was confirmed as a crucial element in the implementation of the policy on media literacy: 
To be able to keep up with the fast digitalization and further mediatization of society, media literacy needs to be further developed in the coming years. I will, therefore, give the Knowledge Center for Media Literacy more responsibilities. I will develop the Center into the reference point for media literacy in Flanders. It will take new actions and develop new initiatives, follow up on actual trends and reach out to specific target groups (our translation, Gatz, 2014).

Although this Policy Note 2014-19 was the work of the Minister of Media and Culture, it is reaffirmed that education plays an important role in media literacy. The Knowledge Center-although financially part of the budget of the media ministry-needs to closely work together with the education sector. As in the Concept Brief on Media Literacy, it is confirmed that media literacy is a transversal issue, deeply focused on digital and social media, that needs to be widely supported by different governmental departments and other players (Gatz, 2014).

\section{The Public Service Broadcaster's Mandate for Media Literacy, 2016-2020}

In the new Management Contract between the Flemish Government and the public broadcaster VRT, for the period 2016 to 2020, media literacy was again included in the contract. This time, media literacy was framed in the context of the average user becoming more active and in relation to the rising importance of digital media in day-to-day life:

The media user is no longer a passive receiver of programs. He has access to platforms that allow the production and distribution of individual content. He can, and this happens increasingly, exchange content through peer-to-peer mechanisms, give feedback to the public broadcaster VRT, be it positive or negative, which has the potential for an interesting dialogue between media user and media professional" (our translation, VRT, 2016).

Within this context, and given the growing importance of digital media and digital communication in daily life, in the relation between citizens and government, in the economy, health, education, etc., being 'media literate' is an important competence for each Flemish citizen. Media users in all strands of society should be able to use media in a conscious, critical and active way. The public broadcasting service should be aware of this and should contribute to media literacy" (our translation, VRT, 2016).

What actions stem from this mandate? Specific targets and outcomes were less precisely developed in this Management Contract than in previous years. Very generally, the contract states that the VRT '(...) should contribute to the media literacy of Flemish media users' (VRT, 2016). After a few general stipulations, Government expects the VRT to develop its internal Action Plan Media Literacy further. The Management Contract does stipulate that the public service 
broadcaster should consult with and work together with external partners such as the Knowledge Center for Media Literacy (VRT, 2016).

\section{The Knowledge Center for Media Literacy - Second Contract}

The first contract organizing the Knowledge Center for Media Literacy ran from 2013 to the end of 2014. The new coalition Government had thus to decide whether or not to prolong the contract-and existence-of the Knowledge Center. As we have discussed, the Minister of Media, Sven Gatz emphasized the importance of media literacy and supported the Knowledge Center in his Policy Note. He even indicated the Knowledge Center could have broader responsibilities, noting:

To help the media users to handle privacy consciously, the Knowledge Center for Media Literacy, in collaboration with all partners involved in policy areas such as education, welfare, and youth will get more scope (our translation, Gatz, 2014).

In 2015, a new contract was signed for the period 2015-17 between the Knowledge Center for Media Literacy and the Minister for Media (Vlaamse Regering, 2014b). The new contract was the result of a consultation process between the Flemish Government, the Knowledge Center and the media literacy stakeholders. As part of this process, the Knowledge Center carried out a broad consultation process with the field, which culminated in a White Paper on Media Literacy (Vanhoucke, 2014). The Knowledge Center also formulated its Vision Text 2015-17 in which it sets out its aims and goals for the three year period (Mediawijs.be, 2014). The new contract foresees a stronger coordinating role for the Knowledge Center, expects a stronger collaboration with private industries, puts more emphasis on the public role of the Center, (e.g., by way of extensive media campaigns), and expects the Center to play a more prominent role in public debates. The budget was raised from 450,000 euro to 600,000 euro annually. In short, Government is expecting that the Knowledge Center shift from a purely intermediate organization to an organization that is more focused on public outreach and public debate.

\section{Conclusion}

As this research demonstrates, media literacy policy in Flanders has shifted over time. Since the mid-2000s, the Parliament-and more specifically individual parliamentarians in the Commission for Media-took the lead in the public discussion of media literacy. Most of these debates were sparked off by discussions on the harmful effects of media on children and youth, on adverse effects of violence in games, on the appropriateness of stricter rules from the Film Rating Authority, or on the problems of opinion formation through the news in digital media.

Ironically, the resulting debates on media literacy did not end in a protectionist attitude towards media, nor in calls for stricter media regulation. Right from the start, parliamentarians and politicians pleaded for an 
emancipatory/empowerment approach to media literacy. The policies later formulated and adopted that same empowerment philosophy. This ambivalent attitude between an initial protectionist reflex and a subsequently more emancipatory approach continues to be part of the current political discussions on media literacy.

The empowerment philosophy seems to be informed by two considerations that emerge throughout all discussions and are also referred to in many of the policies: (1) the realization that a strong and controlling regulatory approach to media in support of the protection of users-more specifically children - is no longer effective in a digital environment; and (2) the belief that the individual is able - in an autonomous and sensible way - to handle and use media individually.

The discussion in Flanders and the position taken in the different policy documents is therefore in line with recent theoretical work on media literacy in the more culturalist tradition, that starts from the autonomy of the public in its relation to media (Buckingham, 2008; Hobbs, 2011b; Hoechsmann \& Poyntz, 2012). Media literacy is seen as a way to support and strengthen critical competences of the user in the absence of stringent media regulation (O'Neill, 2010; Wallis \& Buckingham, 2013). In both the political discussions as in the policy documents, the protectionist reflex remains much more present than in the often optimistic theoretical work on media literacy. Whereas the UK built their policies on more protectionist interpretations of media literacy (Wallis \& Buckingham, 2013), Flanders has taken another position. In the 2008 Policy Brief by the Minister of Media Peeters, media literacy was for the first time mentioned in formal media policy. Emphasis was put on the critical skills a citizen needs to be able to assess information. Later texts and especially the Concept Note on Media Literacy emphasized the creative and communicative skills related to producing and distributing 'user-generated' content. Again this is in line with the 'autonomous,' 'individual' and 'creative' use of media that is often stressed in the empowerment philosophy.

What should be stressed in the Flemish context is that there is less attention to media literacy and citizenship. Often the discussion focuses on social participation and the daily functioning of individuals in society. This participatory approach reflects an awareness that extra initiatives are necessary for more vulnerable and disadvantaged groups in society. In future years, it will be interesting to see whether or not the civic functions of media literacy emerge as a policy priority.

This paper documents how the Flemish Ministers of Media used two central instruments regarding media literacy policy: (1) they set up and financed the Knowledge Center for Media Literacy, (2) they inscribed media literacy in the educational remit of the public service broadcaster VRT. This has resulted in a unique constellation in which media literacy is broadly supported-especially in the Flemish context in which the public service broadcaster plays an important role and has a substantial market share. At first, the Knowledge Center for Media Literacy was mainly seen as an intermediary organization that supports and coordinates existing media literacy initiatives. By inscribing the goal of media 
literacy in the educational remit of the public service broadcaster, the government ensures that the theme reaches a large audience. Seeing that the public service broadcaster also plays an important role vis-à-vis children through its children channel, this is an important age group that can be specifically targeted.

What is interesting to note is that-at least up until now-support for media literacy crosses party lines. The Resolution of Parliament in support of media literacy has been supported by all larger political parties, except for the ultra-nationalist party. Under three different coalition governments-with different constellations of political parties in the coalitions-there has been support for media literacy. The ministers responsible for media-Peeters from the Christian Democratic Party CD\&V, Lieten from the Social Democrat Party sp.a and Gatz from the liberal party, Open VLD - have all supported policies on media literacy. Especially Lieten sp.a and Gatz Open VLD have made media literacy a central theme of their media policies and initiatives.

The case of media literacy in Flanders raises hope for the adoption of national media literacy policies in other countries. Politicians and parliamentarians seem to be well aware of current changes in media and their social consequences. The Flemish case shows that these discussions, which may often focus on the negative consequences, can gradually shift towards empowerment and that different political ideologies can rally around a shared vision for media literacy. This means that media literacy can become a long-term goal that is supported by different political factions and coalitions.

\section{References}

Bens, J., Segers, K., Boudry, E., Van Houcke, L., \& Mariën, I. (2014). Werken aan Mediawijsheid. Veldbeschrijving Mediawijsheid 2013. Retrieved from http://mediawijs.be/sites/default/files/artikels/bestanden/veldtekening_med iawijsheid_2013.pdf

Buckingham, D. (2008). Media education: literacy, learning, and contemporary culture (Repr). Cambridge: Polity Press.

Departement Cultuur, Jeugd, Sport en Media. (2012). Oproep tot het indienen van projectvoorstellen ter inrichting van een Kenniscentrum Mediawijsheid. Vlaamse Overheid.

Frau-Meigs, D., Velez, I., \& Michel, J. F. (2017). Mapping media and information literacy policies: New Perspectives for the governance of MIL. In Public Policies in Media and Information Literacy in Europe. Cross-Country Comparisons (pp. 19-88). Oxon: Routledge.

Gatz, S. (2014). Beleidsnota Media 2014-2019. Vlaamse Regering. Retrieved from https://cjsm.be/media/sites/cjsm.media/files/public/beleidsnota20142019_media.pdf

Hobbs, R. (2011a). The state of media literacy: A rejoinder. Journal of Broadcasting and Electronic Media 55(4), 601 -604.

Hobbs, R. (2011b). The state of media literacy: A response to Potter. Journal of Broadcasting \& Electronic Media, 55(3), 419-430. https://doi.org/10.1080/08838151.2011.597594 
Hoechsmann, M., \& Poyntz, S. R. (2012). Media literacies: A critical introduction. Chichester: John Wiley \& Sons.

IBBT. (2012). Formulier aanvraag projectsubsidie ter inrichting van een Kenniscentrum Mediawijsheid. IBBT, niet publiek document.

Jenkins, H. (2006). Convergence culture: where old and new media collide. New York: New York University Press.

Lieten, I. (2009). Beleidsnota 2009-2014. Media. Vlaamse Regering. Retrieved from https://cjsm.be/media/sites/cjsm.media/files/public/beleidsnota20092014_media.pdf

Lieten, I. (2011). Beleidsbrief Media. Beleidsprioriteiten 2011-12. Vlaams Parlement. Retrieved from https://cjsm.be/media/sites/cjsm.media/files/public/beleidsbrief20112012_media.pdf

Lieten, I., \& Smet, P. (2012). Media Literacy Concept Paper. Brussel: Vlaamse Regering. Retrieved from http://www.ond.vlaanderen.be/ict/english/Flemish-Media-Literacy-PolicyPlan.pdf

Livingstone, S. (2004). Media literacy and the challenge of new information and communication technologies. The Communication Review, 7(1), 3-14. https://doi.org/10.1080/10714420490280152

Marsden, C. T. (2011). Internet co-regulation: European law, regulatory governance and legitimacy in cyberspace. Cambridge, UK ; New York: Cambridge University Press.

Mediawijs.be. (2014). Visie 2015-2017. Vlaams Kenniscentrum Mediawijsheid. Mediawijs.be. Kenniscentrum Mediawijsheid, Intern Document.

Nikoltchev, S., Cappello, M., Cabrera, F., Valais, S., \& Chapman, M. (2016). Mapping of media literacy practices and actions in EU-28. Strasbourg: European Audiovisual Observatory.

O’Neill, B. (2010). Media literacy and communication rights: Ethical individualism in the new media environment. International Communication Gazette, 72(4-5), 323-338. https://doi.org/10.1177/1748048510362445

O’Neill, B., \& Barnes, C. (2008). Media Literacy and the Public Sphere: a Contextual Study for Public Media Literacy Promotion in Ireland. Reports. Retrieved from http://arrow.dit.ie/cserrep/15

Peeters, K. (2008). Beleidsbrief Media Beleidsprioriteiten 2008-2009. Vlaams Parlement. Retrieved from http://docs.vlaamsparlement.be/docs/stukken/2008-2009/g1922-1.pdf

Potter, W. J. (2013). Review of literature on media literacy. Sociology Compass, $7 / 6,417-435$.

Potter, W. J. (2014). Media literacy (Seventh edition). Los Angeles: SAGE.

Vanhoucke, L. (2014). White Paper Mediawijsheid. Aanbevelingen op basis van een sectoranalyse. Kenniscentrum Mediawijsheid. Retrieved from https://mediawijs.be/sites/default/files/nieuws/bestanden/white_paper_med iawijsheid_-aanbevelingen_op_basis_van_een_sectoranalyse.pdf 
Vermeersch, L., Van den Cruyce, N., Vandenbroucke, A., \& Segers, K. (2012). Werken aan mediawijsheid in Vlaanderen. Veldbeschrijving, SWOTanalyse van de actoren inzake mediawijsheid en beleidsaanbevelingen. HIVA KULeuven, Cemeso Vrije Universiteit Brussel.

Vlaams Parlement. (2006). Handelingen. Commissievergadering. Commissie voor cultuur, jeugd, sport en media. Zitting 2005-2006. 1 juni 2006. C266 CUL29. Vlaams Parlement. Retrieved from http://docs.vlaamsparlement.be/docs/handelingen_commissies/20052006/c0m266cul29-01062006.pdf

Vlaams Parlement. (2008a). Handelingen. Commissievergadering commissie cultuur, jeugd, sport en media. Zitting 2007-2008. 15 mei 2008. C240 CUL27. Vlaams Parlement. Retrieved from http://docs.vlaamsparlement.be/docs/handelingen_commissies/20072008/c0m240cul27-15052008.pdf

Vlaams Parlement. (2008b). Handelingen. Commissievergadering commissie cultuur, jeugd, sport en media. Zitting 2007-2008. 15 mei 2008. C244 CUL28. Vlaams Parlement. Retrieved from http://docs.vlaamsparlement.be/docs/handelingen_commissies/20072008/c0m244cul28-15052008.pdf

Vlaams Parlement. (2008c). Handelingen. Commissievergadering commissie voor onderwijs, vorming, wetenschap en innovatie. Zitting 2007-2008. 20 mei 2008. C249 - OND28. Vlaams Parlement. Retrieved from http://docs.vlaamsparlement.be/docs/handelingen_commissies/20072008/c0m249ond28-20052008.pdf

Vlaams Parlement. (2008d). VOORSTEL VAN RESOLUTIE betreffende de ondersteuning van de gamesector in Vlaanderen. Zitting 2007-2008. 5 juni 2008. Stuk 1735 (2007-2008) - Nr. 1. Vlaams Parlement. Retrieved from http://docs.vlaamsparlement.be/docs/stukken/2007-2008/g1735-1.pdf

Vlaams Parlement. (2009). ONTWERP VAN DECREET betreffende de radioomroep en televisie VOORSTEL VAN DECREET houdende wijziging van de decreten betreffende de radio-omroep en de televisie, gecoördineerd op 4 maart 2005, wat de ondertiteling, de Vlaamse Gebarentaal, de audiobeschrijving en de auditieve ondertiteling betreft HOORZITTING VERSLAG namens de Commissie voor Cultuur, Jeugd, Sport en Media uitgebracht door de heren Jurgen Verstrepen en Paul Delva Stuk 214 (2008-2009 - Nr. 3 - 6 februari 2009. Vlaams Parlement. Retrieved from http://docs.vlaamsparlement.be/docs/stukken/20082009/g2014-3.pdf

Vlaamse Regering. (2009). De Vlaamse Regering 2009-2014. Een daadkrachtig Vlaanderen in beslissende tijden. Voor een vernieuwende, duurzame en warme samenleving.

Vlaamse Regering. (2012). Subsidieovereenkomst 2013-2014 tussen de Vlaamse Gemeenschap en iMinds vzw met betrekking tot het Vlaams Kenniscentrum Mediawijsheid. Vlaamse Regering, niet publiek document.

Vlaamse Regering. (2014a). Regeerakkoord Vlaamse Regering 2014-2019. Vertrouwen, Verbinden, Vooruitgaan. Vlaamse Regering. 
Vlaamse Regering. (2014b). Subsidieovereenkomst 2015-2017 tussen de Vlaamse Gemeenschap en iMinds vzw met betrekking tot het Vlaams Kenniscentrum Mediawijsheid. Vlaamse Regering, niet publiek document. von Feilitzen, C., \& Carlsson, U. (2003). Promote or protect? Perspectives on media literacy and media regulations. Göteborg: Nordicom.

VRT. (2012). Beheersovereenkomst 2012-2016 tussen de Vlaamse Gemeenschap en de VRT. Vlaamse Radio en Televisie. Retrieved from http://www.vrt.be/sites/default/files/attachments/Beheersovereenkomst_V RT_2012-2016.pdf

VRT. (2013). Actieplan Mediawijsheid. Vlaamse Radio en Televisie. Retrieved from http://www.vrt.be/actieplan-mediawijsheid

VRT. (2016). Beheersovereenkomst 2016-2020 tussen de Vlaamse Gemeenshap en VRT. Vlaamse Radio en Televisie. Retrieved from http://www.vrt.be/sites/default/files/attachments/Beheersovereenkomst_20 16-2020.pdf

Wallis, R., \& Buckingham, D. (2013). Arming the citizen-consumer: The invention of "media literacy" within UK communications policy. European Journal of Communication, 28(5), 527-540.

https://doi.org/10.1177/0267323113483605 